\title{
Geography and Global Change Science: Relationships Necessary, Absent, and Possible
}

\author{
NOEL CASTREE ${ }^{1,2}$ \\ ${ }^{1}$ Geography \& Sustainable Communities, University of Wollongong, Bldg 41, Northfields Drive, \\ Wollongong, NSW 2522, Australia. \\ ${ }^{2}$ Geography, The University of Manchester, Oxford Road, Manchester M139PL, UK. \\ Email: ncastree@uow.edu.au
}

Received 22 October 2014; Revised 1 December 2014; Accepted 21 December 2014

\begin{abstract}
Initiated by geoscientists, the growing debate about the Anthropocene, 'planetary boundaries' and global 'tipping points' is a significant opportunity for geographers to reconfigure two things: one is the internal relationships among their discipline's many and varied perspectives (topical, philosophical, and methodological) on the real; the other the discipline's actual and perceived contributions to important issues in the wider society. Yet, without concerted effort and struggle, the opportunity is likely to be used in a 'safe' and rather predictable way by only a sub-set of human-environment geographers. The socio-environmental challenges of a post-Holocene world invite old narratives about Geography's holistic intellectual contributions to be reprised in the present. These narratives speak well to many geoscientists, social scientists, and decision-makers outside Geography. However, they risk perpetuating an emaciated conception of reality wherein Earth systems and social systems are seen as knowable and manageable if the 'right' ensemble of expertise is achieved. I argue that we need to get out from under the shadow of these long-standing narratives. Using suggestive examples, I make the case for forms of inquiry across the human-physical 'divide' that eschew ontological monism and that serve to reveal the many legitimate cognitive, moral, and aesthetic framings of Earth present and future. Geography is unusual in that the potential for these forms of inquiry to become normalised is high compared with other subjects. This potential will only be taken advantage of if certain humanenvironment geographers unaccustomed to engaging the world of geoscience and environmental policy change their modus operandi.
\end{abstract}

KEY WORDS geoscience; global environmental change; epistemic communities; inter-disciplinary research; narrative; Geography.

\section{Introduction}

More than most people, researchers and educators believe in the power of knowledge. However, we understand its power is distributed unevenly: for various reasons, some knowledges count more than others. The 2007-2008 global financial crisis is a case-in-point. The dominance of a certain style of economic thinking, particularly in leading Anglophone universities, led to serious intellec- tual blind-spots among financial professionals and financial regulators. Consequently, mainstream economics has been subject to withering criticism in Australia and elsewhere (for example, Quiggin, 2012; Mirowski, 2013). Geographers, of course, have never possessed economists' degree of societal influence. However, knowledge about something that preoccupies a great many of us - namely, the 'human impact' on the physical 
environment - is likely to become uncommonly important in the decades to come.

This is not only because climate scientists have, after years of patient effort, succeeded in getting climate change recognised as a serious global issue in the wider society (organised scepticism now, happily, seems to be on the wane). Beyond this, a much larger, diverse, and international group of geoscientists are today making increasingly alarming claims about the magnitude, scope, and scale of anthropogenic environmental change. These claims amplify and connect those previously made about such things as biodiversity decline and fresh water scarcity. They push to the limits the tone of sobriety normally associated with science. In fact, they mirror, in an empirical register, the political radicalism we normally associate with environmentalism beyond the mainstream. As a recent Nature editorial phrases it, ' . . time is running out, [though] the world is not yet doomed' (2014).

Business leaders and political decision makers will find it ever harder to acknowledge such claims publicly without implementing effective measures to reduce the human impact. After too many years of talk without action, they would likely suffer a credibility crisis by ignoring the profound implications of the robust evidence and forecasts issuing from geoscience. In this light, the question becomes: what stock of knowledge that is to say, information, concepts, and arguments - will be available to inform deliberations and decisions about Earth future? What epistemic communities might jostle to shape debates, and what claims might they make about the post-fossil fuel world we badly need to create?

In this paper I want to address these questions in relation to Geography present and future. My argument will be twofold. First, I think it is highly likely that a relatively small group of human-environment geographers ${ }^{1}$ - those possessed of a broadly 'scientific-analytical' mindset and with desires to be broadly policy relevant will join a wider intellectual 'thought collective'. Indeed, some already belong to it. This collective spans multiple disciplines and is dominated by geoscientists studying global environmental change. It reaches into parts of social science. To the extent its ideas (might) inform debate and societal action, it (will) serve(s) to narrow humanity's future options and aspirations. This is because it largely excludes the insights of critical social science and the humanities. For those geographers already (or aspiring to be) part of the collective, I suspect that talk of such things as the Anthropocene, 'planetary boundaries', and global 'tipping points' will reactivate well-worn narratives about Geography's value as a holistic discipline that reaches the parts others cannot. Such narratives, despite sounding intellectually inclusive, are in my view implicitly exclusionary.

Second, these practitioners and narratives aside, I believe contemporary Geography possesses the intellectual resources to significantly expand people's sense of what Earth futures are desirable and achievable. This alternative contribution to knowledge involves trying to change - rather than conform to - the intellectual framing of anthropogenic environmental change issuing from geoscience and certain elements of social science. It rests on a conception of 'interdisciplinarity' that eschews the singular, holistic pretensions of narratives about Geography's synthetic capacities. It trades confidently on contemporary Geography's heterodox character and wide intellectual bandwidth. The alternative contribution is, I argue, badly needed (though Geography is hardly the only discipline capable of making it). And yet I doubt it will be forthcoming. I suggest that it will prove too challenging to the wider thought collective in universities, think tanks, and foundations who will likely set the agenda for 'necessary and feasible actions' in a post-Holocene world. $^{2}$

As is already obvious from these summary claims, I will be venturing some generalisations about currents of thinking in Geography and beyond. I thereby risk oversimplifying a complicated intellectual landscape. Hopefully, there is more than a grain of truth in the picture I paint. Towards the end of the paper I will also be entering the realms of informed speculation. However, my hope is not simply to predict aspects of the intellectual future, however sketchily. In writing this essay, I want also to shape that future so that the one anticipated here does not come to pass. In short, if some readers share my view about what is likely to eventuate for Geography in respect of reducing 'the human impact' on Earth, they might then ask: how might we act so that the conclusions reached here prove, in time, to be quite wrong?

A quick word on terminology before I proceed. In what follows 'geoscience' refers to the various academic fields devoted to studying Earth surface processes and phenomena (on land, in water, and in the atmosphere). A formal attempt to conjoin these fields is Earth System Science (on which see Wainwright, 2009), though this is scarcely synonymous with geoscience at large. 'Global change science' refers to a 
wider array of disciplines and sub-fields, including those that study 'human dimensions' of environmental change. What these disciplines and sub-fields have in common with geoscience, despite their differences from it, is a belief that society (like 'nature') can be variously measured, modelled, and modified (e.g., by appealing to peoples' rational self-interest). Currently, those most central to global change science are environmental economics, behavioural psychology, political science, environmental planning and those sub-fields that study biophysical hazards, rural land use and urbanisation in broadly scientific-analytical ways. Global change science is thus internally diverse. However, I designate its members a 'thought collective' because I believe they pursue styles of research that bear a family resemblance and (for better or worse) possess a fair degree of commensurability. In recognition of this, some (e.g., Robert Kates, 2011) have attempted to badge and steer the collective with various meta-labels (in his case 'sustainability science').

\section{Geoscientists on the march}

We are accustomed to science changing our world through its evidence, concepts, inventions, and practices. However, research into anthropogenic environmental change is a case of stalled influence. Scientific representations of Earth past, present, and future enjoy a very high profile worldwide; yet the challenge they pose to contemporary capitalist ways of life is being studiously ignored by political economic elites and the majority of citizens. Accordingly, geoscientists are now on the march, using the authority of their profession to change societal thinking about what is considered practically necessary and feasible. Forty years ago, when there was a great surge of concern about Earth's future, only a few scientists stuck their necks out - often controversially so (think of Paul Ehrlich, for instance, the buccaneering biologist and coauthor of The Population Bomb [1968]). Today, by contrast, the concern is being expressed by hundreds of researchers across the environmental disciplines, including some very well respected individuals like Paul Crutzen, James Hansen, and Will Steffen. This is why Naomi Klein (2014), in her new book This Changes Everything, regards geoscientists as potential fifth columnists challenging the present order from within.

In this light, we need to see recent claims about the Holocene's possible end - expressed in the concepts of the Anthropocene (Crutzen and Stoermer, 2000) planetary boundaries (Rockström et al., 2009a) and tipping points (Barnosky et al., 2012) - as more than descriptive-explanatory ones. They are also a strategic attempt by groups of geoscientists, notably in Europe, to exert political influence in the wider world. This is graphically evident in Johan Rockström et al.'s notion of a 'safe operating space for humanity'. To use the well-known distinction associated with advice dispensed by the Intergovernmental Panel on Climate Change (IPCC), these groups are trying harder than ever to be policy relevant while somehow remaining 'policy neutral'. They are thereby discharging an awesome responsibility. What other domain of academic inquiry permits practitioners to make claims about the world that stand to become claims upon all those inhabiting that world? This sort of epistemic universalism is rare in any walk of life, cross-cutting as it does differences of society and situation. It comes with obligations and risks.

There are clear signs that geoscientists believe three changes to their modus operandi are necessary if they are to exert greater societal influence in future. First, some argue that the (worrying) evidence and forecasts about global environmental change need to be broadcast to non-academic constituencies in a more forthright and direct way. For instance, writing in Nature Climate Change, Anderson and Bows (2012) criticise their colleagues for pulling their punches about the political implications of scientific findings. Meanwhile, Berkeley ecologist Anthony Barnosky et al. (2014) have led by example, authoring a succinct synthesis document for political decision makers - the 'Scientific consensus on maintaining humanity's life support systems in the $21^{\text {st }}$ century'. This document is not circumscribed in content or tone in the way that publications by formal reporting bodies like the IPCC - or the younger Intergovernmental Platform on Biodiversity and Ecosystem Services - are.

Second, it is increasingly clear to geoscientists that the large environmental changes humans are causing will rebound on societies significantly. So far, the bulk of global change inquiry - represented for a generation by four international research programmes ${ }^{3}$ - has focused largely on biogeochemical changes and scenarios. Geoscientists are now calling for interdisciplinary research that links studies of human behaviour, institutions, and regulations with studies of the Earth's changing physical geography. Such 
integrative inquiry, it is hoped, will make global change research more relevant to 'mitigation' and 'adaptation' policies. As a prominent statement in Science put it, 'research dominated by the natural science [should] transition toward research involving the full range of [social] science and humanities' (Reid et al., 2010, 917). More recently, Phillip Sharp and Alan Leshner of the American Association for the Advancement of Science - have called for 'convergence science' that 'integrat[es] ... knowledge from the life, physical, social and economic sciences and engineering' (2014, 579). One example of these aspirations is provided by Paul Palmer and Matthew Smith, writing in Nature. They call for new Earth system models that can build-in human actions and responses because omitting these is 'like designing a bridge without accounting for traffic' $(2014,365)$. Such models will, it is hoped, bring people and nature into a single analytical domain, aspiring to mirror in a computational environment real-world couplings between socio-economic and physical systems.

Finally, several leading geoscientists have proposed a 'new social contract' wherein their research becomes more applied and 'solutions orientated' (see Brito and Stafford-Smith, 2012; DeFries et al., 2013). This promises to take the idea of 'policy relevant' inquiry closer to highlevel decision making and nearer the coal-face where practical measures to address environmental change are implemented. It involves setting the general strategic aims of public policy - such as new UN-sponsored Sustainable Development Goals (see Griggs et al., 2013). However, more concrete 'actionable science' is also envisaged that will see global change researchers propose new technologies and new 'behaviour change' measures (see Palmer, 2012; Sivapalan et al., 2014).

These three proposed alterations to the working practices of geo-scientists are being made at an important moment for the logistics of global change inquiry. A global Future Earth research programme (http://www.icsu.org/future-earth) is now in its formative stages as a successor to the International Geosphere-Biosphere Program (among other things). It already looks like it will internalise the expressed desire for more forthright, interdisciplinary, and relevant forms of socio-environmental inquiry (see Gaffney, 2014). This is echoed in plans for important national level programmes, such as the next phase of America's global change research (USGCRP, 2012).

\section{Geography and global change science}

These developments represent an exciting opportunity for many geographers to make their research count beyond the discipline and outside the academy. They also ask questions of Geography's current capacity to take advantage of this opportunity. We have been here before, of course. However, where Geography was only lightly involved in the great surge of environmental concern, policy and activism during the late 1960s, today the 'environmental agenda' is quite central to the discipline in a range of different ways. The question is not so much whether, but how and to what degree, geographers might make their voices heard as societies confront accelerating environmental change.

Answering this question directs us, in the first instance, to those human-environment geographers who already belong to, or are aligned with, the geoscientific networks described above. These practitioners are interested in influencing the drama of human-environment relations from one or other side of the society-nature dualism that has long organised research and teaching in Geography. They include the likes of Eric Lambin (of the universities of Louvain and Stanford - who researches land use change by linking remotely sensed and socio-economic data); Tim Lenton (of Exeter University - an earth system scientist with expertise in modelling and 'tipping elements'); Erle Ellis (of the University of Maryland - a biogeographer who studies anthropogenic ecosystems); Diana Liverman (of the University of Arizona - who has studied people's vulnerability to the effects of climate change, among many other things); Neil Adger (who, like Lenton, is at Exeter University - his major focus is the measurement and enhancement of social resilience to environmental change); and Jon Barnett (of Melbourne University - who examines social adaptation to climate change and environmental in/security). These individuals (and there are several others one could mention) are hardly of a piece. Some are geographers by background (e.g., Liverman), others not (e.g., Lenton). The intellectual differences between them speak to the diversity and complexity of the geoscience networks they are, in different ways, plugged into. However, at different times and in different ways they have joined geoscientists' recent march to get anthropogenic environmental change taken far more seriously in the wider world.

For instance, Lambin, Lenton, and Liverman all lent their names to the planetary boundaries 
idea that was first presented in papers in Nature and Ecology and Society (Rockström et al., 2009a; 2009b). Erle Ellis, meanwhile, has associated himself with the Anthropocene concept on several occasions (e.g., Ellis, 2011). Then, Ellis, Lambin, and Liverman were among the co-authors of a notable manifesto for a new style of 'can do' global change science focused on 'planetary opportunities' (DeFries et al., 2013). Liverman has recently co-led authorship of the Future Earth design plan with Johan Rockström (Liverman and Rockström, 2014). Finally, through their work on recent IPCC assessment reports, both Adger and Barnett have helped to bring 'human dimensions' more to the fore in global change science. They have done so - and are hardly alone in this - by employing a broadly 'scientific-analytical' language that makes sense in global change research arenas long dominated by environmental chemists, biologists, and so on. This language talks about 'drivers', 'factors', 'causes', 'effects', 'responses', and 'feedbacks'. It also resonates in policy circles where decisions ultimately have to be made about how societies can mitigate and adapt to anthropogenic environmental change.

Looking ahead, one can see how the wider developments in global change science represented in Future Earth provide considerable opportunity for more geographers to work in this vein. The 'human-environment' problematic today enjoys unprecedented intellectual and practical importance in higher education and the wider world. Various geoscience subjects are central to engaging that problematic, along with certain strands of social science (e.g., environmental economics). The latter are set to become more important as human adaptation to a changing Earth becomes a priority in the decades ahead. To the extent that they share a 'structure of feeling' with these subjects and strands, many geographers are likely to make formative contributions to knowledge and policy in the years to come.

\section{Narratives that galvanise ... and constrain}

All disciplines employ narratives to make sense of their past, present, and possible future. Narratives impose order on what was, is, and could (or should) be. The recent developments in geoscience, along with the growing impact of humans on Earth, dovetail well with familiar stories about Geography's identity and value for society. These stories emphasise the discipline's proclaimed determination to bring what we call 'nature' and society within one or other analytical frame, cross-cutting several spatio-temporal scales. They accent Geography's synthetic ambitions as a 'weaver', whereas more specialist subjects tend to be 'spinners'. They serve to anticipate and justify the need for Geography to make its voice heard loudly in academic, policy, and public debates about humanity's escalating effects on the planet. ${ }^{4}$

A recent example is offered by Carol Harden (2012), in the published version of her conference address as president of the American Association of Geographers (see also Ziegler et al., 2013). Like many others before her - notably Melvin Marcus (1979), David Stoddart (1987), Robert Kates (1987), Ron Cooke (1992), Patricia Gober (2000), Billie Lee Turner (2002), and David Skole (2004) - Harden uses narratives about Geography's late 19th-century origins and 20th-century evolution to make claims about its current state and future prospects. She reviews different 'framings' of human-environment interactions in years past, not so much to advocate any one of them in the present as to legitimate the claim that they cover the 'core area' of Geography. Referencing external developments like those summarised earlier in this paper, Harden concludes that 'the opportunity costs to Geography of not bringing our intellectual resources to bear are great' $(2012,745)$. She then observes that

If Geography is a disciplinary doughnut, with important gaps at the center of its intellectual space, then we have a research frontier right at our core. This internal frontier offers new opportunities to integrate our full range of expertise as geographers, from the natural science perspectives of physical geography to the carefully nuanced understandings of those working with people and institutions, to fill critically important research gaps, identified not only by ourselves but also by others. (2012, 745)

In short, Harden uses both a story about Geography's past and external opportunities in the present to enjoin more practitioners to cross the 'human-physical' divide so as to produce integrated and relevant knowledge.

It is not difficult to anticipate a narrative like this being reprised by leading humanenvironment geographers as the society-nature problematic assumes ever greater importance in universities and the wider society. Like all narratives, Harden's is both constructed and 
normative. This does not mean it is presented in bad faith, or is deliberately manipulative. Narratives can inspire us - for instance, I remember as an undergraduate being very energised by the late David Stoddart's (1987) plea to reinvigorate Geography's 'man-land' tradition (as he called it at that time). Narratives can act as critical commentaries on roads taken as compared with ones that might (have) be(en) taken. In the present case, they could be used to inspire more geographers to follow in the footsteps of Lambin, Liverman, Adger, and others. Given geoscientists' determination to extend the scope and influence of their inquiries, the 'geographical advantage' appears to be the ensemble of expertise already existing in a single disciplinary space and practitioners' synthetic habits. We cover Earth systems and 'human dimensions' in one subject, and - unlike in previous decades - seem fairly well placed to tackle the analytical and practical challenges of an Earth transformed (see Ziegler et al., 2013).

However, just as narratives can forge identity and purpose among their addressees, they can also alienate and divide. This has two aspects. First, some addressees may simply not relate to the narratives at all. In Geography there have long been physical and human geographers who rarely dwell in the marchlands between the two fields. For them arguments about Geography's need for great coherence centred on society-nature interactions are either irrelevant or overbearing. Second, some addressees may respond to the spirit but not the letter of the narratives. In the present case, there are many geographers deeply interested in human-environment relations and very concerned about the future of the planet. I count myself among them. However, they will not be persuaded that Geography should sell itself as what Skole (2004) called 'the pre-eminent interdisciplinary environmental discipline' whose time has now come. Other narratives are possible and desirable, as I will show below. First, however, let us consider in more detail the character of the "Geography: humans + environment $=$ synthesis' narrative, along with its shortcomings. Over the years, and still today, this narrative has been especially prominent in North America. There it has been used to 'market' Geography to researchers and others outside the discipline. For instance, it is evident in the US National Research Council agenda-setting report Understanding the Changing Planet: Strategic Directions for the Geographical Sciences (2010). This doubtless reflects Geography's lower standing in the academic pecking order compared, say, with the UK.

\section{A troubling narrative-practice loop}

\section{Real and unexamined presuppositions}

I suggest there has been a fairly consistent, if often implicit, set of ontological and epistemological beliefs underpinning long-standing narratives about Geography and the study of human-environment relationships. For some geographers they are almost disciplinary common-sense. They are encapsulated in this excerpt from Harden's presidential address:

For geographers, sustainability research invites integration of all types of geographic expertise. It needs the knowledge provided by those who study human impacts and human adjustments and offers a wide research frame that encompasses interdisciplinary efforts, outreach to stakeholders and practitioners, and research that once would have been considered 'applied.' To be effective, it will need to incorporate feedback in the humanenvironment system, as achieving sustainable human-environment interactions will require cultural, economic, philosophical, and engineering change. $(2012,742)$

If we unpack this (complex) claim, and contextualise it in previous Annals of the Association of American Geographers articles about Geography's 'true calling', we discover a number of suppositions. First, it is assumed there is one world whose interconnected character demands integrative inquiry. Second, it is assumed that the epistemological challenge is to connect the metaphorical jigsaw pieces so that the full picture is revealed. This presupposes commensurability (conceptual, methodological, etc.) between the analysis of humans and of physical environments. Third, it is assumed that real world actors can articulate their needs and wants such that these can be incorporated in suitably bespoke, applied research outcomes. Finally, it is assumed that Geography should work in a largely cognitive and responsive register, providing information and proposals that will dovetail with real world events (e.g., observed biophysical changes or new political agendas for environmental management). The metaphor of 'system' positions geographers as observercontrollers trying to make things work better.

These beliefs are consistent with the vision many geoscientists have for more forthright, 
interdisciplinary, and relevant global change science. Indeed, several human-environment geographers have directly addressed geoscientists in precisely these terms, perhaps understanding that they seem uncontentious to their intended audience. For instance, writing in Science Diana Liverman, Billie Lee Turner II, and Tom Wilbanks, among others, make the case for what they call 'practice-relevant adaptation science' (Moss et al., 2013). Because the global environment will undoubtedly change and because societies will have to respond, the authors argue for an 'adaption science ... . needed to understand decision processes and information requirements, identity vulnerabilities, improve foresight about climate risks and other stressors, and understand barriers and options for adaptation' (p. 696). Throughout the paper, the physical and human worlds are depicted as amenable to integrated, actionable analysis; 'problems' are seen to emerge 'out there' beyond universities and the job of geographers and others is to respond through joined-up research and tailored information/advice. Similar views underpin Robin Leichenko et al.'s call for enhanced 'vulnerability science' in the pages of Nature Climate Change (Stern et al., 2013). The authors propose interdisciplinary vulnerability analysis across a range of environmental and social systems that can 'provide the basis for identifying and assessing options proactively and to improve and hasten recovery' (p. 609). They position themselves, and their readers, as public servants who can anticipate and reduce peoples' risks to environmental change by assembling more - and more 'relevant' - socio-environmental evidence.

These sort of technocratic-managerial arguments are perfectly good ones, as far as they go. They echo those made for over a decade by Robert Kates (e.g., 2011) - advocate of 'sustainability science' - and for over 30 years by Turner II (e.g., 2009) - champion of 'land change science'. Such arguments are routinely made flesh in multi-investigator research projects, where the rhetoric of integrated, applied inquiry is substantiated. However, the public-spirited expert role they imagine geographers and others to play belies their deeply political character; so too does the rather bland language of 'problems', 'risks', 'options', and 'decisions' that animates them. Geographers can and should play a role in a more engaged, worldly form of global change science that seeks to alter that which it studies. However, it would be wrong to think that things like adaptation, vulnerability, sustainability, and land change science are the only, or best, contributions to make. Such contributions, consistent as they are with a certain disciplinary selfunderstanding, suffer a double weakness. First, they invite human-environment geographers to reproduce - because they refuse to fundamentally question - the current political economic and cultural order of things. It is, of course, precisely this order that is the biggest threat to human and non-human life on Earth (as Klein [2014] shows). Second, by bracketing questions of power, inequality, values, social dissent, and ethics, such contributions screen-out a range of important contributions being made by humanenvironment geographers who work in different registers. It is a measure of how hegemonic a broadly scientific worldview is in global change research that those geographers currently involved have found few opportunities to challenge its political character.

\section{Questions and criticisms}

As I mentioned in passing earlier, Geography's metaphorical 'core' is now far more heavily populated than 40 years ago (notwithstanding Harden's claim otherwise). However, today's human-environment geographers are a heterodox group, particularly on the 'human side' of the disciplinary middle-ground. Research like Eric Lambin's or Jon Barnett's represents only part of their collective activity. Consider the contributions made by political ecologists (e.g., Ribot, 2014), animal geographers (e.g., Gibbs et al., 2015), analysts of agro-food systems (e.g., Bock and Buller, 2013), and many others besides. Much of their activity does not instantiate the narrative favoured by Harden and previous disciplinary notables. Yes, they aspire to 'joined-up' analysis of a world where society and environment now bleed into one another. However, their research gives us reason to question the four suppositions that underpin narratives about Geography's synthetic ambitions and proclaimed value as a holistic discipline. Why so?

First, the 'one world' assumption (otherwise known as ontological monism) is philosophically questionable. Why not a world of worlds? And, even if we agreed we inhabit a single, hypercomplex reality, there is no possibility that all aspects of it could be captured in a single analytical or normative template that would trump all others (cf., Stallins, 2012). This is clear in recent studies by geographers of how to manage invasive species, which highlight the alternative framings available and the fact that 'objective' 
evidence cannot adjudicate them (see Robbins and Moore, 2013). Second, the assumption that chunks of knowledge can (at one or other operational scale) be pieced together to reveal the 'whole picture' needs qualifying. The 'parts' one identifies through research and the 'reality' they reveal (once 'properly' connected) are surely relative to cognitive, moral, and aesthetic worldviews. For instance, where climate scientists might favour mechanical metaphors by abstracting from 'nature' in certain ways, a researcher investigating indigenous peoples' 'adaptive responses' may need to relinquish the categories of Western thought so as to see their world from the inside-out. Recent geographical research into water resources makes this abundantly clear (see Wilson, 2014). Third, the assumption that listening to 'stakeholders' will better help geographers tailor their research raises big questions about suitable forms of dialogue and professional learning. For instance, a major contribution of political ecology over the years has been to show that many users of land and water are variously ignored, marginalized, and often unable (for a variety of reasons) to articulate their 'real' needs and wants (see, for instance, Peluso et al., 2008). In this light, 'stakeholder engagement' becomes a complex, political, and possibly protracted affair. Finally, the assumption that geographers (should) work largely in a cognitive and responsive mode unduly circumscribes their potential contributions. Why should they not challenge and change external agendas pertaining to things like global environmental change? Why should they not bring moral and even aesthetic questions into the heart of their attempts to describe, explain, and change the world? Why can they not utilise Geography's mix of scientific, technical, critical, and humanistic approaches in novel ways towards new ends?

\section{Geography and the prospect of a new kind of global change science}

I have suggested that some geographers are set to play their part in the consequential unfolding of global change science, based on previous and current contributions, networks, and narratives. However, I have questioned the intellectual and practical agenda these geographers' research is likely to serve, looking ahead. I believe that global change science needs to proceed in a less resolutely scientific-analytical register. Anthropogenic environmental change raises profound human questions - such as 'how should we live with each other and non-humans?' Answers to these questions vary according the worldviews of different communities, cultures, and societies. This means that the power of logical reasoning and factual evidence cannot operate in abstraction nor presume to universal purchase. Global change science can no longer externalise all this in its attempts to describe, explain, and predict multi-scalar socio-environmental dynamics. There is more to 'human dimensions' than the observation of peoples' perceptions and preferences, or of the 'carrots and sticks' that govern the day-to-day behaviour of individuals and organisations. How, then, to open the brackets?

There are interesting things afoot in Geography suggestive of an answer to this question. I use Sarah Whatmore's term 'minority interdisciplinarity' $(2013,173)$ to describe them. These things are not (yet) formally referenced to global change science in the main. Those pursuing them are not (yet) usually plugged-in to the wider networks coalescing around the Future Earth initiative. However, their inquiries hint at a different style of human-environment geography than that commended in conventional disciplinary narratives. They might thereby inspire new self-understandings productive of new aspirations. If work in this vein could gain mass and momentum in the years immediately ahead, Geography might then make a different contribution to global change science than that imagined in the narratives of Harden, Kates, and fellow travellers. Currently absent, I believe this contribution is necessary. Let me summarise three examples of this work from both hemispheres before distilling some take-home lessons.

\section{Flood risk and management: a British science experiment}

In recent years, a set of British human and physical geographers have together experimented with a new form of 'integrated' inquiry. Funded by both the Economic and Social Research Council and the Natural Environment Research Council, they have sought to enact the analysis and management of flood risk in novel ways (Lane et al., 2011; Donaldson et al., 2013; http://relu.data -archive.ac.uk/explore-data/search-browse/ project/?ID=RES-227-25-0018). In England, academic, government, and private sector scientists have long dominated such analysis and management. Through the Environmental Agency (EA) - the governmental body mandated to assess and reduce flood risk - a series of approaches and methods have become well- 
established. These include hydrological and hydraulic models, and cost-benefit analysis of possible risk mitigation and prevention strategies. In recent years, the EA has paid more attention to communicating and consulting with those affected by flooding.

One of the research team's case areas was Pickering in North Yorkshire. This small town is adjacent to a river with a catchment of around 70 $\mathrm{km}^{2}$. It has been inundated several times in the last 15 years. When the team arrived there in 2007, Pickering had just suffered a major flood. Previous risk assessments overseen by the EA had acknowledged the town's vulnerability. However, cost-benefit analysis of proposed measures to control water flows in and around the town had produced gridlock. The measures, framed by standard hydrological evidence and predictions, were deemed too costly. They had also proven to be controversial among some locals. As a result, flooding was a recognised problem in Pickering but even major flood events were not catalysing new, more effective management practices.

In this context, the research team resolved to undertake an experiment in producing knowledge in a different way so as to 'unfreeze' the situation. They collaborated with a small group of local residents to take a fresh look at the flooding problem and possible solutions to it. The so-called Ryedale Flood Research Group comprised locals, physical scientists (e.g., Stuart Lane) and social scientists (e.g., Sarah Whatmore). It had several in-depth meetings, between which sustained work was undertaken by group members. In these meetings the hydrologists not only sought to explain the scientific approaches typically used to assess flood risk. They also questioned them and incorporated locals' knowledge of the wider catchment above Pickering. Meanwhile, the social scientists did not seek merely to 'elicit' local views through interviews or focus groups. Instead, they engaged them as co-researchers in producing new ideas about how and where to institute hitherto unconsidered flood control measures. This process was participatory for all involved in ways more organic and less procedural than established EA methods of local engagement.

The result - emergent rather than planned from the get-go - was the production of a different model for representing water flows in the catchment area. This model incorporated landscape elements that had been glossed in the EA-led assessment process. It was usefully decoupled from that process and generated possible new proposals that previous cost-benefit analyses had not been able to consider. The principal one was to institute a set of small dams ('bunds') in areas of the upstream flood plain to regulate water flow into Pickering Beck. This idea, novel in the Pickering context (if not elsewhere), proved far less controversial and more cost-effective than previous measures. It created room for manoeuvre where none apparently existed. It only arose because of a willingness to experiment with flood risk analysis - 'experiment' in the sense of trying things out with no certain sense of the outcomes. As Lane et al. put it,

The purpose of [physical and social] science had shifted from problem-solving and analysis in ways that tend to give [it] . . . hegemony in the decision-making process, to the practice of science as a ... political intervention, making Ryedale and its local community 'heard' and unsettling the established positions of institutions and professionals ... $(2001,32)$

In sum, the research team did far more than identify hitherto 'hidden' physical and human dimensions of the Pickering flood drama. They also pushed beyond standard forms of 'public engagement' that has become de rigeur in contemporary science policy in many Western countries. The team, in effect, performed a different 'problem definition' and identified novel solutions by refusing the standard expert-lay relationship. In this process, knowledge of environment and society emerged organically and relationally. It was 'useful' knowledge, but in more democratic, less formalised ways than that issuing from the established EA processes.

\section{Registering and learning from Country: novel Australian research collaborations \\ All empirical inquiry is underpinned by episte- mological and ontological assumptions: they are the hidden bed-rock upon which observation, interpretation, and intervention occur. Although one set of assumptions are common-sense for some, for others they are alien and may be experienced as an imposition. Conversely, unlearning one's taken-for-granted beliefs is a way not only to discover different worldviews; it can also be experienced as a form of personal reinvention that might sway others to relinquish what they consider to be axiomatic. \\ Here in Australia geographers at the Univer- sity of Newcastle and Macquarie University have}


been inviting their peers to rethink the means and ends of research by attending to Country. Like other settler colonies, modern Australia is founded on an historical geography of physical and cultural violence towards aboriginal peoples. Classically, 'giving voice' to these peoples in the academic arena has involved anthropologists and geographers undertaking sustained fieldwork in order to understand indigenous life-worlds from the inside. Kate Lloyd, Sandie Suchet-Pearson, and Sarah Wright have pushed far beyond this classic practice in their path-breaking research on, with, and for Bawaka Country in north east Arnhem Land, part of Australia's Northern Territory (Bawaka Country et al., 2013; 2014; Wright et al., 2012).

Over a period of years the trio has developed very close relationships with individuals and families who inhabit Bawaka Country. These relationships have led them not merely to understand indigenous cosmology. More profoundly, they have endeavoured to embrace this cosmology in the conduct and dissemination of their research. This has involved seeing themselves as not as analysts of Country but as elements of Country. Bawaka, as Wright et al. (2012, 54) report,

... incorporates people, animals, plants, water and land. But Country is more than just people and things; it is also what connects them to each other and the multiple spiritual and symbolic realms. It relates to laws, custom, movement, song, knowledges . . . histories, presents, futures ... country can be talked to, it can be known, it can itself communicate, feel and take action.

In this light, the trio have fundamentally questioned the standard protocols of academic research into people and non-humans.

Methodologically they departed from the norm of putative neutrality that so often underpins academic observation of the world. They also pushed beyond sight and sound as privileged senses and allowed themselves to invest emotionally in Bawaka rather than purely intellectually. These methodological choices allowed them to understand Country in a way arguably impossible if they had treated it as a cultural construction there to be 'documented', however faithfully. Lloyd, Suchet-Pearson, and Wright have let Country alter their research practices rather than expecting it to be intelligible using the procedures and categories of Western academia. This tracks through to how they report their inquiries. For instance, in a recent Cultural Geographies paper - perhaps the most striking contribution in that journal's pages for many years - Bawaka Country is the 'lead author' (more accurately 'sole author', as explained below).

This highly unusual move is no gimmick. Instead, it is a provocation to the article's readers: it says 'Accept this article not only as a representation of Country but as an extension of Country'. It invites readers to read with 'embodied responsiveness' (Bawaka Country et al., $2014,10)$ and to be moved by the 'ethics of care' (ibid.) definitional of aboriginal relations with human and non-human others. It also raises serious questions about the adequacy of textual representation, the prevalent medium in which Western societies still disseminate knowledge. Can Bawaka Country 'speak itself' to readers like us on the pages of an academic journal or via a monograph? Does it challenge us to do better than rely on words and still images consumed at a distance?

From a physical geography (and wider geoscience) perspective, all this may appear as interesting cultural 'context' but might be thought to do nothing to alter established practices of researching rivers, landforms, etc. in what indigenous peoples call Country. However, in a novel 'human-physical' collaboration, Deirdre Wilcock, Gary Brierley and Richie Howitt (2013) argue otherwise. Taking the case of both basic and applied research in geomorphology, they consider how indigenous cosmologies might inspire something they call 'ethnogeomorphology'. As Wilcock et al. argue, these cosmologies share a family resemblance with ideas of 'emergence' and 'space-time relationality' in geomorphology, themselves contemporary forms in which the field's idiographic traditions live-on. The difference is that the cosmologies are actively lived by indigenous peoples and possess ethical dimensions. The authors invite geomorphologists to de-objectify landscapes and understand their own research as both affecting - but standing to be affected by - the material world (including human lives as physical, moral, and affective landscape elements). They call for a more reflexive, critical landform analysis conscious of its own particular framings of the real and its imbrication in contexts (often marked by power asymmetries) where the human and the physical cannot be cleanly separated, either analytically or materially. As Jeremy Walker (2013) shows, such 
awareness could challenge the neo-colonialism of Western environmental policy approaches from the inside. This is not the same as saying that such approaches, and the research underpinning them, has no value. Instead, it is to relativise and provincialise them in ways we are (still) not accustomed to, even after 25 years of postcolonial scholarship.

\section{Facts and values in water resource governance: a New Zealand critique}

The distinction between 'facts' and 'values' continues to organise the broad academic division of labour and underpins the familiar notion of 'evidence-based policy' (where researchers are supposedly 'policy relevant' while remaining 'policy neutral'). As Bruno Latour (2004) and others have long argued, it is also politics by other means: in the name of 'facts' researchers can secrete specific values that dovetail with certain interests in the wider society but not others. This is not to say researchers fabricate evidence (wittingly or otherwise) to fit their favoured values. Instead, it is to say that once value judgements are made, they are a key parameter defining what evidence counts and, in turn, what sort of policies that evidence can feasibly speak to. Such judgements are typically presented in the language of 'objectivity' and 'logic' in natural science and in the 'harder' parts of the social sciences. This can serve to 'lock-in' these judgements without them being made explicit or, where necessary, debated by those who stand to be affected by them down the line (Wynne, 2014).

In recent research into a holistic assessment tool used in freshwater management, Marc Tadaki and Jim Sinner (2014) argue strongly that all research on environment and people - both alone and together - contains contingent and contestable value judgements that demand scrutiny. The novelty of their case lies in its empirical focus: namely an attempt, by New Zealand water professionals, to render different values explicit and transparent by linking environmental and social data. Tadaki and Sinner show that, in their desire to account for stakeholders' varied valuations of freshwater, these professionals institute their own value-set in the framing of what societal values are admissible in the River Values Assessment Systems (RiVAS).

To be more specific, from the 1990s, ecologists and conservation planners have been tasked by New Zealand law to produce composite measures of the quality of river systems with a view to ranking them comparatively. More recently, regional governments have been tasked with identifying people's valuations of these systems to aid decisions about managing water quality and quantity. Again, these valuations were to be referenced nationally, necessitating a method of eliciting them in a standardised form in different parts of New Zealand. The result was (is) a seemingly comprehensive mapping of both environmental and social values by combining physical science and social science methods.

However, Tadaki and Sinner demonstrate two important things. The first is that the RiVAS only captured one kind of 'value', which they term 'contribution to a goal'. For instance, the System asks people how much river $\mathrm{X}$ is valued as a place to swim or fish. The second is that this decision to exclude methods to record other ways people might value rivers - Tadaki and Sinner identity three $(2014,142)$ - was itself a value judgement, but one shielded from public scrutiny. Made by water resource professionals, the decision presumed that rivers matter to people most as possible means to certain instrumental or recreational ends. For this reason, Tadaki and Sinner argue that the RiVAS does not, in fact, 'represent' peoples' values but is itself what they call a 'value articulating institution' (p. 148, emphasis added) - this despite its apparent commitment to 'give voice' to otherwise mute stakeholders. The flaw in the System, the duo argue, is the pretence to record facts and values objectively as if the recording process is a neutral way-station to fully informed water management cognisant of both physical and social dimensions.

\section{Local lessons for disciplinary and global agendas}

Though conducted independently of each other, the recent studies I have just highlighted demonstrate the merits of what we might call 'wide and deep' forms of socio-environmental inquiry. They are critical of 'narrow and shallow' forms but also self-reflexive about their own preferred approaches. Narrow and shallow forms presume scientific knowledge can bracket value questions and piece together data about physical and human dimensions, such that normative issues arise 'downstream'. By contrast, the studies summarised above refuse, in their different ways, to make hard distinctions between cognitive, ethical, and aesthetic issues, between objectivity and subjectivity, between means and ends, between is and ought. However, they do not 
presume to muddy those distinctions according to a single ontological or epistemological template. We might take this as an acknowledgement of the wide range of ways in which the practices of environmental science, social science, and the humanities can articulate. In the case of Geography specifically, these studies incite us to cross the 'human-physical' divide in ways that standard narratives of disciplinary unity scarcely imagine. Each one not only questions, but offers an alternative to, at least one of the four assumptions that underpin the discourse of Geography as a 'synthetic' subject. They speak to forms of knowledge that, yes, are 'integrated' but in what we might call 'cosmopolitical' ways.

By virtue of this, these studies also speak to the threefold agenda of today's geoscientists in a constructive and suggestive manner. For instance, the lessons of Bawaka Country are that the very ideas of 'interdisciplinary' and 'actionable' global change science are contingent on the underlying worldviews one takes to be salient at one or other scale of analysis. Then, the RiVAS study challenges any presumption that social scientists can deal with value questions among 'stakeholders' in value-free ways analogous to geoscientists' studies of Earth systems. Finally, the Pickering study suggests that 'actionable knowledge' can involve much more than 'consulting' those who stand to be affected by that knowledge. It contains its own politics and potentialities that place responsibilities on researchers as agents rather than just serviceminded analysts. As part of this, there is the risk - if that is the right word - that research gets packaged to meet the perceived needs of policymakers or dominant stakeholders, and little else besides.

The examples I have showcased may, of course, seem too local and too radical to be instructive for global change science as it enters a new phase. After all, global change science is concerned with analysis and intervention at the planetary scale, cascading down to regions and places. Moreover, as noted earlier, critical social science and the environmental humanities are not well represented in the relevant networks and dialogues. However, this is precisely why global change science needs an injection of new blood before analytical and normative practices get solidified in consequential new research programmes (see Castree et al., 2014). The merit of the examples I have presented is they are concrete. Rather than offer abstract arguments about 'minority interdisciplinarity', they serve as dem- onstration cases of what is possible. They offer us hope that what Jerome Kagan (2009) calls the 'three cultures' divide in academia cannot only be bridged but spanned in plural, creative ways.

\section{Conclusion}

A few years ago Mike Hulme (2008) - geographer turned climate-scientist turned geographer once again - argued that Geography has more to offer debates on climate change than an 'integrated understanding' of human-environment couplings. 'By stripping climate of its flowing cultural and psychological symbolism, [and] by ignoring the multiple meanings of climate', Hulme opined, 'we are in danger of letting the idea of climate change get out of control' (p. 10). His argument is relevant to understandings of global environmental change more broadly. Such change is not a single, complex, planet-wide socio-physical hybrid existing 'out there'; nor does it act back upon humans as an objectively knowable set of processes and effects. Looking ahead, it will not be experienced the same the world over - materially, emotionally, morally, or aesthetically. Neither will it, could it or should it trigger similar responses; moreover, whatever the particular situation there is more than one 'right' response. Global change science, and all those subjects that try to understand and shape humanenvironment relationships, should be aiming to understand and alter the differentiated landscape of matter, meaning, and affect that is life in the Anthropocene. The changing Earth will not should not - be itself changed by recourse to one or other form of expert analysis as if it is a patient seeking certified medical attention.

Geography will sell itself short if it rests content with anything less. Worse, geographers who might otherwise challenge the current modus operandi of many global change researchers will, in effect, be endorsing the status quo. Here I return to my opening reference to economics and the 2007-2008 financial crisis. By analogy, we can ask what might happen if we allow things like agent-based models, behavioural psychology and green economics to set the agenda for the human response to environmental change. What sort of world will emerge - and which worlds never stand a chance of eventuating - if alternative framings of the actual, the possible, and the desirable are rendered largely invisible?

In Geography, this is a rather pointed question for two groups of researchers and educators one much larger than the other. On the one hand, 
and as described earlier in this essay, there is a relative minority of human-environment geographers who are already plugged-in to the world of global change science. For at least some of them, the challenge is this: can their 'insider' status be used to render less muscular the scientificanalytical framing so characteristic of the wider 'thought collective'? I say some because a number of practitioners wear more than one intellectual hat. Diana Liverman is an excellent example: she is very alive to the ways that geoscience is political for good and ill. In different writings, she has played alternative roles, sometimes that of scientific analyst (e.g., Richardson et al., 2011), sometimes that of science and policy critic (Lovell and Liverman, 2010). She has combined them to good effect, helping to legitimise the study and mitigation of socioenvironmental vulnerability in hitherto physical science-dominated sections of American global change research. On the other hand, you have a much larger group of human-environment geographers who, like those mentioned in the previous section, are neither linked to nor intellectually aligned with global change science. Many of these geographers see the connective imperative between cognitive, ethical, and aesthetic matters, and between reason and emotion. For at least some of them, the challenge is this: with like-minded others outside Geography, can they build connections to global change science that might serve to redirect the whole enterprise?

Sadly, I suspect the answer is 'no', despite some efforts in this direction (e.g., Brannstrom and Vadjunec, 2013). For all sort of practical and intellectual reasons, they would likely find the challenge too much. Meanwhile, other geographers - and a whole cadre of global change scientists - will continue to misdescribe socioenvironmental change as a complex of 'problems' in need of technical and behavioural 'solutions' as part of a much hoped for 'sustainability transition'. As Hulme (2014) argues in his new book Can science fix the climate?, different approaches are urgently needed. They would marry description, explanation, and prescription in plural ways reflective of divergent human values and mindful of deep asymmetries of power and authority. They would open-up our sense of what issues and goals matter to diverse constituencies, and what kind of interventions seem necessary, wise or just. They might thereby foster debate and multiply options, openly acknowledging the politics written into all knowledge-claims about Earth present and future. Such practices are, interestingly, hinted at in the high-profile World Social Science Report 2013 (ISSC \& UNESCO, 2013) and a new European agenda for publicly funded science (Felt, 2013). As I have argued, some geographers are already practising the sort of wide and deep 'minority interdisciplinarity' that Hulme advocates. They invite us to see Geography as, in Susan Smith's felicitous words,

... an enterprise of relatedness whose vitality is secured by ... pulling the world apart, reassembling it, and adding to it in a variety of intruiging, ethically charged, sometimes surprising and frequently controversial ways. (2005, 389)

Let us hope these practices can inspire new narratives and further innovative inquiries that, in quick time, change the relations between Geography and the wider world of global change science.

\section{NOTES}

1. In this paper I use the term 'human-environment geography' to refer to a range of studies conducted into the relationships between people and the biophysical world. Some prefer the term 'environmental geography' (see, for instance, Castree et al., 2009).

2. The bare bones of this paper were first conjured in the form of a plenary lecture given at the 2014 IAZ-NZGS joint conference in Melbourne. I want to thank the conferences organisers Brian Cook and Ian Rutherford for the kind invitation to speak. This lecture, I now realise with the benefit of hindsight, was the fruit of ideas seeded by Karen O'Brien in her 2010 report published in Progress in Human Geography. Since this report, I have also taken inspiration from arguments about a 'critical physical geography' (Tadaki et al., 2014), among other things.

3. I am referring to the International Geosphere-Biosphere Program, launched in 1987, which followed the World Climate Research Program, created in 1980. They were followed by the International Human Dimensions Program (1990) and Diversitas (launched in 1991 and focusing on global biodiversity and biogeography).

4. My sometime co-editor and colleague David Demeritt (2009a; 2009b) has usefully identified two ways in which Geography's special relevance to the 'environmental agenda' has been proclaimed. One is to say that Geography contains within it all or most of the specialisations one needs to understand past, present, and future humanenvironment relations. The other is to say that geographers possess synthetic habits of mind that make them especially important in enabling the sort of 'joined-up' research that connects specialisms together to comprehend the tapestry of human-environmental relations. In what follows I focus on the second argument, which constitutes a more ambitious 'selling' of Geography's credentials than the former.

5. The 2015 AAG meeting in Chicago uses the term 'radical intra-disciplinarity', one favoured by current Association President Mona Domosh and suitably evocative of what I am trying to get at in this part of the paper. 


\section{REFERENCES}

Anderson, K. and Bows, A., 2012: A new paradigm for climate change. Nature Climate Change 2, 639-640.

Barnosky, A.D., Hadly, E.A., Bascompte, J., Berlow, E.L., Brown, J.H., Fortelius, M., Getz, W.M., Harte, J., Hastings, A., Marquet, P.A., Martinez, N.D., Mooers, A., Roopnarine, P., Vermeij, G., Williams, J.W., Gillespie, R., Kitzes, J., Marshall, C., Matzke, N., Mindell, D.P., Revilla, E. and Smith, A.B., 2012: Approaching a state shift in Earth's biosphere. Nature 486, 52-58.

Barnosky, A.D., Brown, J.H., Daily, G.C., Dirzo, R., Ehrlich, A.H., Ehrlich, P.R., Eronen, J.T., Fortelius, M., Hadly, E.A., Leopold, E.B., Mooney, H.A., Myers, J.P., Naylor, R.L., Palumbi, S., Stenseth, N.C. and Wake, M.H., 2014: Introducing the Scientific consensus on maintaining humanity's life support systems in the 21 st century: information for policy makers. The Anthropocene Review 1, 78-109.

Bawaka Country, Suchet-Pearson, S., Wright, S., Lloyd, K. and Burarrwanga, L., 2013: Caring as Country: towards an ontology of co-becoming in natural resource management. Asia Pacific Viewpoint 54, 185-197.

Bawaka Country, Wright, S., Suchet-Pearson, S., Lloyd, K., Burarrwanga, L., Ganambarr, R., Ganambarr-Stubbs, M., Ganambarr, B. and Maymuru, D., 2014: Working with and learning from Country: decentring human author-ity. Cultural Geographies, doi: 10.1177/1474474014539248.

Bock, B. and Buller, H.J., 2013: Healthy, happy and humane: evidence in farm animal welfare policy. Sociologia Ruralis 53, 390-411.

Brannstrom, B. and Vadjunec, J.M. (eds), 2013: Land Change Science, Political Ecology, and Sustainability: Synergies and Divergences. Routledge, New York.

Brito, L. and Stafford-Smith, M., 2012: State of the planet declaration. Retrieved: 7 October 2014 from <http:// www.planetunderpressure2012.net/pdf/state_of_planet _declaration.pdf>.

Castree, N. et al. (ed.), 2009: A Companion to Environmental Geography. Wiley-Blackwell, Oxford.

Castree, N., Adams, W.M., Barry, J., Brockington, D., Büscher, B., Corbera, E., Demeritt, D., Duffy, R., Felt, U., Neves, K., Newell, P., Pellizzoni, L., Rigby, K., Robbins, P., Robin, L., Rose, D.B., Ross, A., Schlosberg, D., Sörlin, S., West, P., Whitehead, M. and Wynne, B., 2014: Changing the intellectual climate. Nature Climate Change 4, 763-768.

Cooke, R., 1992: Common ground, shared inheritance: research imperatives for environmental geography. Transactions of the Institute of British Geographers 17, 131-151.

Crutzen, P.J. and Stoermer, E.F., 2000: The Anthropocene. Global Change Newsletter 41, 17-18.

DeFries, R. et al., 2013: Planetary opportunities. BioScience 62, 603-606.

Demeritt, D., 2009a: From externality to inputs and interference: framing environmental research in geography. Transactions of the Institute of British Geographers 34, 3-11.

Demeritt, D., 2009b: Geography and the promise of integrative environmental research. Geoforum 40, 127-129.

Donaldson, A., Lane, S., Ward, N. and Whatmore, S., 2013: Overflowing with issues: following the political trajectories of flooding. Environment \& Planning C 31, 603-618.

Ehrlich, A. and Ehrlich, P., 1968: The Population Bomb. Ballantine Books, New York.

Ellis, E., 2011: Anthropogenic transformation of the terrestrial biosphere. Philosophical Transactions of the Royal Society A 369, 1010-1035.
Felt, U., 2013: Science in Society: Caring for Our Futures in Turbulent Times. European Science Foundation, Strasbourg.

Gaffney, O., 2014: Quiet green revolution starts to make some noise. Nature 505 (30th January), 587.

Gibbs, L., Atchison, J. and Macfarlane, I., 2015: Camel country: assemblage, belonging and scale in invasive species geographies. Geoforum 58, 56-67.

Gober, P., 2000: In search of synthesis. Annals of the Association of American Geographers 90, 1-11.

Griggs, D., Stafford-Smith, M., Gaffney, O., Rockström, J., Öhman, M.C., Shyamsundar, P., Steffen, W., Glaser, G., Kanie, N. and Noble, I., 2013: Policy: sustainable development goals for people and planet. Nature 495, 305-307.

Harden, C., 2012: Framing and reframing questions of human-environment interactions. Annals of the Association of American Geographers 102, 737-747.

Hulme, M., 2008: Geographical work at the boundaries of climate change. Transactions of the Institute of British Geographers 33, 5-11.

Hulme, M., 2014: Can Science Fix the Climate? Polity, Cambridge.

ISSC \& UNESCO, 2013: World Social Science Report. UNESCO, Paris.

Kagan, J., 2009: The Three Cultures. Cambridge University Press, New York.

Kates, R., 1987: The human environment: the road not take, the road still beckoning. Annals of the Association of American Geographers 77, 525-534.

Kates, R., 2011: What kind of a science is sustainability science?, Proceedings of the National Academy of Sciences of the United States of America 108, 19449-19450.

Klein, N., 2014: This Changes Everything. Simon \& Schuster, New York.

Lane, S.N., Odoni, N., Landström, C., Whatmore, S.J., Ward, N. and Bradley, S., 2011: Doing flood risk science differently. Transactions of the Institute of British Geographers $36,15-36$.

Latour, B., 2004: Politics of Nature. Harvard University Press, Cambridge, MA.

Liverman, D. and Rockström, J., 2014: Future Earth Design Report. ICSU, Paris.

Lovell, H. and Liverman, D., 2010: Understanding carbon offset technologies. New Political Economy 15, 255-273.

Marcus, M., 1979: Coming full circle: physical geography in the 20th century. Annals of the Association of American Geographers 69, 521-532.

Mirowski, P., 2013: Never Let a Good Crisis Go to Waste. Verso, London.

Moss, R.H., Meehl, G.A., Lemos, M.C., Smith, J.B., Arnold, J.R., Arnott, J.C., Behar, D., Brasseur, G.P., Broomell, S.B., Busalacchi, A.J., Dessai, S., Ebi, K.L., Edmonds, J.A., Furlow, J., Goddard, L., Hartmann, H.C., Hurrell, J.W., Katzenberger, J.W., Liverman, D.M., Mote, P.W., Moser, S.C., Kumar, A., Pulwarty, R.S., Seyller, E.A., Turner II, B.L., Washington, W.M. and Wilbanks, T.J., 2013: Hell and high water: practice-relevant adaptation science. Science 342, 696-698.

National Research Council, 2010: Understanding the Changing Planet: Strategic Directions for the Geographical Sciences. The National Academies Press, Washington.

Nature, 2014: Warming up. Nature 514 (1st October), 5-6.

O'Brien, K., 2010: Responding to environmental change: a new age for human geography?, Progress in Human Geography $35,542-549$.

Palmer, M., 2012: Socio-environmental sustainability and actionable science. BioScience 62, 5-6. 
Palmer, P. and Smith, M., 2014: Model human adaptation to climate change. Nature 512 (28th August), 365-366.

Peluso, N.L., Suray, A. and Rachman, N.F., 2008: Claiming the grounds for reform: agrarian and environmental movements in Indonesia. Journal of Agrarian Change 8, 377408.

Quiggin, J., 2012: Zombie Economics: How Dead Ideas Still Walk among Us. Princeton University Press, Princeton.

Reid, W.V., Chen, D., Goldfarb, L., Hackmann, H., Lee, Y.T., Mokhele, K., Ostrom, E., Raivio, K., Rockström, J., Schellnhuber, H.J. and Whyte, A., 2010: Earth system science for global sustainability: grand challenges. Science 330, 916-917.

Ribot, J., 2014: Cause and response: vulnerability and climate in the Anthropocene. The Journal of Peasant Studies 41, 667-705.

Richardson, K., Steffen, W. and Liverman, D. (eds), 2011: Climate Change: Risks, Challenges, Decisions. Cambridge University Press, Cambridge, UK.

Robbins, P. and Moore, S., 2013: Ecological anxiety disorder. Cultural Geographies 20, 3-19.

Rockström, J., Steffen, W., Noone, K., Persson, Å., Stuart Chapin III, F., Lambin, E.F., Lenton, T.M., Scheffer, M., Folke, C., Schellnhuber, H.J., Nykvist, B., de Wit, C.A., Hughes, T., van der Leeuw, S., Rodhe, H., Sörlin, S., Snyder, P.K., Costanza, R., Svedin, U., Falkenmark, M., Karlberg, L., Corell, R.W., Fabry, V.J., Hansen, J., Walker, B., Liverman, D., Richardson, K., Crutzen, P. and Foley, J.A., 2009a: A safe operating space for humanity. Nature $461,472-475$.

Rockström, J., Steffen, W., Noone, K., Persson, A., Stuart Chapin III, F., Lambin, E., Lenton, T.M., Scheffer, M., Folke, C., Schellnhuber, H.J., Nykvist, B., de Wit, C.A., Hughes, T., van der Leeuw, S., Rodhe, H., Sörlin, S., Snyder, P.K., Costanza, R., Svedin, U., Falkenmark, M., Karlberg, L., Corell, R.W., Fabry, V.J., Hansen, J., Walker, B., Liverman, D., Richardson, K., Crutzen, P. and Foley, J., 2009b: Planetary boundaries: exploring the safe operating space for humanity. Ecology \& Society 14, 32.

Sharp, P. and Leshner, A., 2014: Meeting global challenges. Science 343, 579.

Sivapalan, M., Konar, M., Srinivasan, V., Chhatre, A., Wutich, A., Scott, C.A., Wescoat, J.L. and Rodríguez-Iturbe, I., 2014: Socio-hydrology: use-inspired water sustainability science for the Anthropocene. Earth's Future 2, 225-230.

Skole, D., 2004: Geography as a great intellectual melting pot and the preeminent interdisciplinary environmental discipline. Annals of the Association of American Geographers 94, 739-743.

Smith, S., 2005: Joined-up geographies. Transactions of the Institute of British Geographers 30, 389-390.
Stallins, A., 2012: Scale, causality and the new organismenvironment interaction. Geoforum 43, 427-441.

Stern, P.C., Ebi, K.L., Leichenko, R., Olson, R.S., Steinbruner, J.D. and Lempert, R., 2013: Managing risk with climate vulnerability science. Nature Climate Change 3, 607-609.

Stoddart, D., 1987: To claim the high ground: geography for the end of the century. Transactions of the Institute of British Geographers 12, 327-336.

Tadaki, M. and Sinner, J., 2014: Measure, model, optimise: understanding reductionist concepts of value in freshwater governance. Geoforum 51, 140-151.

Tadaki, M., Brierley, G., Dickson, M., Le Heron, R. and Salmond, J., 2014: Cultivating critical practices in physical geography. The Geographical Journal, doi: 10.1111/ geogj.12082.

Turner, B.L., II, 2002: Contested identities: humanenvironment geography and disciplinary implications in a restructuring academy. Annals of the Association of American Geographers 92, 52-74.

Turner, B.L., II, 2009: Land change science. In Castree, N. et al (ed.) A Companion to Environmental Geography. Wiley-Blackwell, Oxford, 168-180.

USGCRP, 2012: The national global change research plan 2012-22. Retrieved: 7 October 2014 from <http:// www.globalchange.gov/browse/reports/national-global -change-research-plan-2012-2021-strategic-plan-us-global -change $>$.

Wainwright, J., 2009: Earth system science. In Castree, N. et al (ed.) A Companion to Environmental Geography. Wiley-Blackwell, Oxford, 145-167.

Walker, J., 2013: Worlds to endure: weathering disorder from Arnhem Land to Chicago. Global Networks 13, 391-409.

Whatmore, S., 2013: Where natural and social science meet? Barry, A. and Born, G. (eds) Interdisciplinarity: Reconfigurations of the Social and Natural Sciences. Routledge, London, 161-177.

Wilcock, D., Brierley, G. and Howitt, R., 2013: Ethnogeomorphology. Progress in Physical Geography 37, 573-600.

Wilson, N.J., 2014: Indigenous water governance: insights from the hydrosocial relations of the Koyukon Athabascan village of Ruby, Alaska. Geoforum 57, 1-11.

Wright, S., Lloyd, K., Suchet-Pearson, S., Burarrwanga, L., Tofa, M. and Bawaka Country, 2012: Telling stories in, through and with country. Journal of Cultural Geography 29, 39-60.

Wynne, B., 2014: Further disorientation in the hall of mirrors. Public Understanding of Science 23, 60-70.

Ziegler, A.D., Gillen, J., Newell, B., Grundy-Warr, C. and Wasson, R.J., 2013: Comprehensive research in geography. Area 45, 252-254. 